UDC 332.146 .2

DOI: $10.15587 / 2312-8372.2018 .134820$

Calinescu T., Zelenko $\mathbf{0 .}$

\title{
ANALYSIS OF PUBLIC INSTITUTES ACTIVITY AS INSTRUMENT OF SETTLEMENT THE ECONOMIC RELATIONS OF REGION
}

Об’єктом дослідження виступають громадські інституиії, діяльність яких створює певні умови для поліпшення позитивної динаміки розвитку економічних відносин у регіонах, особливо у Донещькій $i$ Луганській областях (Украӥна). Вибір об’єкту обумовлений високим рівнем соціальної напруженості та низьким рівнем довіри населення органам влади на всіх рівнях державного управління. Тому виникає об'єктивна потреба у дослідженні особливостей формування громадянського суспільства на сучасному етапі розвитку України, а саме інститущій, які реалізують процес участі населення у прийнятті поточних рішень щодо вирішення проблем сочіально-економічного розвитку регіонів країни.

В ході дослідження за допомогою методів аналізу та синтезу, аналогї та порівняння, а також методу формалізаиіі:

- запропоновано покроковий алгоритм аналізу діяльності і громадських інституцій, що діють на регіональному та місцевому рівні;

- оглянуто основоположні документи, нормативно-законодавчі і регуляторні акти, що регламентують діяльність структур, покликаних реалізовувати прочедури участі громадськості під час формування та реалізацї державної, регіональної сощіально-економічної політики, вирішення питань місцевого значення.

Крім того, в ході дослідження проаналізована поточна ситуація щодо діяльності досліджуваних інституцій на прикладі Луганської області. Ідентифіковано, що серед двох виявлених типів організацій, які покликані реалізовувати механізм взаємодії влади, бізнесу та населення, наявний тільки один. На сьогоднішній день функціонування даних структур розглядається суто у площині процесу державного управління. Результативність та економічна ефективність їх діяльності фактично не здійснюється.

Враховуючи виявлені недоліки, дублювання функиій та неефективну діяльність існуючих громадських інституцій запропоновано провести їх реорганізацію та створити на базі існуючих - одну структуру. Ця структура покликана об’єднати всіх учасників соціального діалогу задля формування результативних партнерських відносин та проведення позитивних реформ у соціально-економічному розвитку регіонів, та успішного врегулювання економічних відносин регіонів з державою.

ключові слова: процес державного управління, громадські інституиї, розвиток економічних відносин y регіонах.

\section{Introduction}

The development of civil society in Ukraine is an urgent problem of the last decade.

The turning point in the development of relations between authorities and society were the events of 2014. They demonstrated that, despite the declaration of the political course of state leadership in direction of active interaction with the population, ordinary citizens do not trust any power structure, both at the national and regional levels.

On the other hand, among many civil institutions, there are no any organization which in recent years has shown itself to be a real opinion representative and a defender of the population rights. Despite the large number of normative, legislative and regulatory acts, in Ukraine it is not created a favorable climate for the development of a socially active and responsible civil society. As a result, citizens of the country are not involved in the current management process for the development of their region, in spite of the fact that all formal signs of population engagement to this process are exist.

\section{The object of this research and its technological audit}

The object of research is public institutions, which activities create certain conditions for improving the positive dynamics of economic relations in the regions, especially in Donetsk and Lugansk regions (Ukraine). Studies conducted on the territory of these areas by sociological Ukrainian and international organizations of Canada, America and Germany have shown [1] that the attitude and behavior of the population of these territories is not significantly changing in dynamics. Four years of fighting in the East of Ukraine, raising the level of socio-economic development, strengthening the image of Ukraine on the international arena, did not break the confidence of the population majority regarding the need to give special status to non-controlled territories of Ukraine. Despite researchers dispute about certain mistakes in the survey of inhabitants of uncontrolled territories, this confidence is only growing - $43 \%$ of respondents in 2017 and $33 \%$ of those surveyed from the controlled territories. For comparison - in 2016 it was $31 \%$ and $37 \%$ respectively [1]. 
Among the main reasons for such a situation, which has almost complete coincidence in the inhabitants of both territories - there are [1]:

- the struggle of other states for their sphere of influence in Ukraine. This was confirmed by $33 \%$ of the respondents in the controlled territory and $27 \%$ - uncontrollable territory in 2017; in 2016 - $33 \%$ and $30 \%$ respectively;

- the struggle of the Ukrainian oligarchs for the spheres of influence in the state, which is reflected in figures: $29 \%$ of the polled inhabitants of the controlled territory and $33 \%$ - on uncontrollable territory in 2017 and accordingly in $2016-27 \%$ and $34 \%$.

And among the main problems of 2017, forcing people to remain in these positions are:

- intensification of hostility in relation to each other: $60 \%$ of the respondents in the Donetsk region and $81 \%$ - on uncontrollable territory;

- low living standards - $53 \%$ of the interviewed inhabitants of the controlled territory and $40 \%$ - on uncontrollable territory;

- frozen conflict - respectively $20 \%$ of inhabitants of the controlled territory and $35 \%$ - on uncontrollable territory.

All this confirms the need for political, social dialogue in the country, especially in the East, with the participation of certain branches of government, political parties, business and population, involving public Ukrainian and international institutions.

\section{The aim and the objectives of research}

The aim of research is development of practical and methodological recommendations for assessing the impact of public institutions activity in the context of economic relations settlement in the region, which requires solving the following tasks:

1. Definition of indicators for evaluation of public institutions activities.

2. Determination of the factors of public institutions influence on the state of regional socio-economic development.

3. Measurement of public institutions influence on economic relations in the region.

4. Determination of effectiveness and efficiency in the implementation of recommended methodological approaches.

\section{Research of existing solution of the problem}

Interpretations of the goals and objectives of public institutions activity are currently enough presented in the domestic economic literature [2, 3]. However, the question of determining the indicators for assessing the impact of their work on the state of economic relations in the region is not yet sufficiently highlighted. In addition, it is quite controversial and complex, which cannot be answered unambiguously:

- firstly, the answer and indicators search for assessing the impact of public institutions on the regulation of economic relations is on the verge of perceptions of different methods and evaluation methods. They relate to various research tools used to reveal sociological, psychological, economic and technological aspects, and have an interdisciplinary character. One science ac- knowledges them, and the other does not perceive it unequivocally, since nobody has abolished the methods of dialectics and methods of cognition;

- secondly, each region can have its own informal approaches for regulating economic relations, and therefore it is difficult to measure the impact of this factor;

- thirdly, current laws «On Information» [4], «On State Statistics» [5] and National Accounting Standards [6] do not stipulate the collection and accumulation of information on the activities of public institutions. Moreover, they restrict the provision of any other information not provided by law, which creates certain difficulties in determining the degree of economic regulation;

- fourthly, there is no clear quantitative and qualitative definition of what indicators should be measured by economic relations [7-9], which in the modern period acquire a social tone;

- fifthly, foreign experience cannot be neglected [10,11], with regard to the definition of results, the diagnosis of different systems of indicators and the achievement of goals through work in certain associations.

\section{Methods of research}

During the work execution, the following general scientific methods of research were used:

- analysis and synthesis for the preliminary analysis of the situation in the field of social activity and the formation of the research problem, to determine the purpose and tasks formulation;

- analogies and comparative comparisons for research of existing solutions for existing problems, as well as for the characterization of the activities of various public institutions;

- formalization method for presenting the study results, specifically for drawing up an the solving problem algorithm.

\section{Research results}

It is proposed to solve the set aim and objectives according to the following algorithm of actions:

Step 1. Choosing a method for measuring and evaluating the activities of public institutions.

The results of any activity can only be obtained by measuring [8]:

1) quantitative (cardinal) when using a single measure. However, when it is absent, the following method is used;

2) ordinary methods of measurement, that is, when it is possible to measure in a certain order according to the advantages: «more - less», «better - bad», «above - low», etc.;

3) structured measures complex have a set (plurality, vectors) of various parameters that characterize a certain reality as an integral entity.

If adapt existing measurement methods to the solution of the tasks set for assessing the impact of public institutions activity on economic relations in the region, then it is possible to use both 2) and 3) methods. And here researchers have the right to choose the way that most and substantially will bring the institution to positive socio-economic transformations in the region.

Step 2. Selection of traditional values (postulates) characterizing development, positive movement of economic relations in the region. 
The forms of economic relations in the era of globalization tend to converge, which is called Europeanization [8]. However, it is inappropriate to use the widespread belief that societies with different historical cultures are so similar to each other that they can interact. Therefore, the existing economic forms of relations in different states and regions are unpredictable, but all of them are based on the classical theories of society economic development, and hence on certain value orientations [8]:

1. Human needs are limited, and its possibilities are limitless. The basis of this postulate is human capabilities and knowledge that can change the goals of society, using them in the public interest.

2. The theory of spiral development, which has its parallels with the inversely gradual nature of history movement. Proceeding from this theory, it is possible to predict further forward movement rather clearly and predictably.

3. Everything historically new is advanced, although it may have certain features and the same problems as in the past. However, it is the fact what process that only is preparing for implementation, does not carry the inverse of a gradual nature.

4. Recognition of public morality (public opinion) - an independent driving force capable to move society forward in spite of any circumstances. This postulate is old as the world, because all the revolutions, reforms and transformations in the states take place on behalf of the people, in their interests and in order to achieve the goals of society.

5. The idea of achieving economic justice. And the perception of justice in each society is different: from primitive equalization to social (social well-being).

So, it is possible to choose the traditional values for the priority values, those to which are moving any modern society, which aims to achieve decent (generally accepted) socio-economic well-being, level of education, culture and quality of life.

Step 3. Determining the attitude of society to the existence of public institutions in the region.

At this stage, surveys, questionnaires, discussion clubs, regional seminars and other events can be held during a certain period of time. Due to this, there is a coincidence in the dynamics of certain thoughts about the positive activities of public institutions and the need to overcome in their work certain conflicts in the region. Also, in the process of such work, certain benefits can be expressed in the attitude of the population towards certain institutions and how quickly they react to changes in the priorities of the population and help to achieve them.

There is no sense to provide analytical, statistical, graphical, economical and mathematical methods that can be used to substantiate the results obtained at this stage. However, it should be noted that social values should be realistic, measured by the extent of their achievement and respond to the interests of the region population.

Step 4. Evaluating the impact results of public institution's activities on economic relations in the region.

Regardless of the existing systems for evaluating the effectiveness, any set of indicators with the following attributes for evaluation can be used to analyze the results of the influence of public institutions on the economic relations of the region:

1) it is determined by existing classical indicators of performance evaluation;

2) has non-standard indicators for measuring performance;
3) can be fixed in the standard, statistical, and formal reports;

4) the ability to monitor these indicators (indicators) in dynamics;

5) the possibility to obtain this indicator at different levels of economic relations management;

6) the possibility of establishing the causes and consequences of the results obtained;

7) the opportunity to motivate and stimulate the receipt of positive indicators;

8) establishing feedback between the public institution and the regional community in order to overcome negative marks;

9) combination of performance indicators;

10) orientation towards the achievement of the public institution's mission;

11) flexibility and multi-dimensionality for evaluation of institution's activity results;

12) the possibility for adapting to the reporting of a public institution;

13) predictability, comparability and the possibility of correlation analysis to select the most relevant indicator;

14) setting up a collaborative work for getting positive results in the process of discussion and other communications.

Of course, not all indicators can take into account all defined attributes, but public institutions can conduct a rating of criteria, which will determine a certain system of performance indicators, which will be adopted as a basis.

Step 5. Making decisions concerning further activities of the public institution.

This step summarizes the results of the public institution activities and provides an inventory of current initiatives to revise, correct or change the strategy of impact on economic relations.

At this stage, comparative tables may be compiled, in which the initiatives (activity description) presented by the institution and the goals that were achieved through the implementation of a particular initiative will be recorded. Horizontally - executed initiatives and vertically achieved goals may have some commonly used performance indicator that will signal the effectiveness of the institution's activity and the need for new initiatives or adjustments to existing ones (Table 1 ).

All that is listed in the Table 1 with the sign «-» is an excuse for further work aimed at improving the results of the initiatives, and all that with the «+» sign is an occasion for disseminating the experience of implementing this initiative to achieve other goals.

«The National Strategy for the Promotion of Civil Society Development in Ukraine for 2016-2020» was approved by the Decree of the President of Ukraine in February 2016 [12]. The strategy highlights a number of key issues that need to be addressed during its implementation. Including:

- non-transparency for bureaucratic interaction between public authorities and local self-government bodies with the public;

- non-controllability of the Ukrainian authorities to the Crimean peninsula and parts of the Luhansk and Donetsk regions;

- imperfection of the current legislation in the field of realization of public initiatives;

- non-compliance of Ukrainian legislation with the state standards of the European Union and ignoring of positive world experience in this area of activity. 
An example of drawing up a comparative table of existing initiatives and goals

\begin{tabular}{|c|c|c|c|c|c|c|}
\hline Goals $\quad$ Initiatives & $\begin{array}{l}\text { Expansion of partner- } \\
\text { ship with business }\end{array}$ & $\begin{array}{l}\text { Awareness of the popu- } \\
\text { lation through the media }\end{array}$ & $\begin{array}{l}\text { Conducting of } \\
\text { training seminars }\end{array}$ & $\begin{array}{l}\text { Cooperation with international } \\
\text { foundations and organizations }\end{array}$ & $\begin{array}{l}\text { Distribution of } \\
\text { grants programs }\end{array}$ & \\
\hline $\begin{array}{l}\text { Ensuring employment } \\
\text { of population }\end{array}$ & +1 & -1 & +1 & -1 & +1 & +1 \\
\hline $\begin{array}{l}\text { Reducing of population } \\
\text { migration }\end{array}$ & -1 & +1 & $-1^{\prime}$ & +1 & +1 & +1 \\
\hline $\begin{array}{l}\text { Small and medium bu- } \\
\text { siness development }\end{array}$ & +1 & +1 & +1 & +1 & +1 & +1 \\
\hline $\begin{array}{l}\text { Increasing the income } \\
\text { level of the population }\end{array}$ & -1 & -1 & -1 & -1 & -1 & +1 \\
\hline $\begin{array}{l}\text { Improvement of the re- } \\
\text { gion's infrastructure }\end{array}$ & +1 & -1 & -1 & +1 & -1 & +1 \\
\hline$\ldots \ldots \ldots \ldots$ & +1 & +1 & +1 & +1 & +1 & +1 \\
\hline
\end{tabular}

The stated strategic directions include:

1. Creation of favorable conditions for the formation and institutional development of civil society organizations.

2. Ensuring effective procedures for public participation in the formation and implementation of state, regional policy, addressing issues of local importance.

3. Stimulation of the participation of civil society organizations in the socio-economic development of Ukraine.

4. Creation of favorable conditions for inter-sectoral cooperation.

Consideration of the implementation of this strategy at the level of the Luhansk region, which is the most backward depressed region over the last three years, has allowed such results to be obtained. Thus, an analysis of the existing regional plans of measures in the Luhansk region and the relevant reports, in the framework of the implementation of the above-mentioned national strategy [13], showed that:

- despite the fact that the strategy is being implemented

3rd year already and full two years are behind of its implementation, the report about the implementation of the planned measures is submitted only in 2017;

- most part of these activities are duplicated from year to year, but neither in the plan nor in the implementation report shows the degree of progress in the indicated strategic directions. It seems that there is no positive dynamics at all.

During a detailed research of the situation in the field of civil society formation, it was revealed that public councils, which should be formed in all executive and local government bodies, are the main instrument for the implementation of the aforementioned strategy. Today it is the only one consultative and advisory body that implements the mechanism of interaction between state authorities and the population, but its activities are subject to constant criticism and are actively discussed both by academics and practitioners. Among the main drawbacks are noted [14]:

- incompetence with regard to the problems of a particular territory or sphere of activity and the absence of clearly specified requirements for the professional training of public councils members;

- irresponsibility of public councils members for attending meetings, as well as absence of responsibility system for their inactivity;

- unsatisfactory coverage of public council activity results;
- recommendatory character of the decisions, respectively, lack of guarantees of their implementation by the authorities;

- lack of stable sources of funding for the activities of public councils.

The modern paradigm of the mankind existence requires the observance of stable socio-economic development concept, the balance between the economic, social and environmental components and active interaction between the authorities, business and the region's population. However, public councils within the framework of this concept are an inadequate tool that virtually ignores the presence of economic agents in the region. The analysis of the existing membership of the members of the public council in the regional state administration of Luhansk oblast has revealed in it the majority of civic organizations representatives dealing with social problems of the population and specific socially vulnerable groups [15]. But, the share of persons representing the economic environment of the region is too small. Among the 35 members of the council, only four persons represent the interests of trade union organizations, two of which are representatives of various territorial branches of one trade union, and three persons are representatives of business associations. With such a number of people they cannot influence by their authority to make important socio-economic decisions for the Luhansk region.

Public councils are formed and implement their activities in the field of public administration. On the other hand, in the sphere of economic relations, another public institution was created, which is intended to implement a mechanism of coordinated interaction between the government, employers and employees. This is the National Tripartite Social and Economic Council with territorial branches in each oblast (except Luhansk and Donetsk). This structure, together with the National Mediation and Reconciliation Service, is intended to implement the principles of social dialogue and create favorable conditions for the development of social partnership. The members of the National Council include representatives of executive power, trade unions and employers of Ukraine [16]. Moreover, within the framework of the work of the National Council, the Committee on Civil Society Development and International Relations is constantly functioning. 
In the absence of the National Tripartite Social and Economic Council in the Luhansk region, there is a need for coordinating public institutions and directing their activities to positive changes in the economic relations of the region.

A comparative analysis of the basic activity principles for each structure has been proved (Table 2):

- despite the commonality of the ultimate goal (establishing a process of stable interaction between the authorities, representatives of the economic environment and ordinary citizens), the activities of the two structures are interconnected;

- both structures don't realize their tasks in full:

1) in the case of public councils work, the participation of business representatives is limited;

2) there are no representatives of any public organizations other than trade unions and employer associations in the national council;

- the real socio-economic results from the work of both structures are not presented to the general public. All reports in most cases contain information on planned activities, but the event itself is not a result, but only one of the mechanisms for achieving the goals set;

- it is not clear from the activity of both institutions on official sites that their work is correlated within the implementation of the State Strategy for Regional Development [19] and relevant territorial strategies for socio-economic development.

Table 2

Comparative characteristic of the basic functioning principles for Public Council and the National Tripartite Social and Economic Council

\begin{tabular}{|c|c|}
\hline Public Council & $\begin{array}{c}\text { National Tripartite Social and Economic } \\
\text { Council }\end{array}$ \\
\hline \multicolumn{2}{|r|}{ Main tasks } \\
\hline $\begin{array}{l}\text { - Creation of conditions for } \\
\text { the citizens to exercise their } \\
\text { constitutional right and to par- } \\
\text { ticipate in the management of } \\
\text { public affairs. } \\
\text { - Facilitating to consideration } \\
\text { by the executive body of public } \\
\text { opinion during the state policy } \\
\text { formation and implementation. } \\
\text { - Implementation of public } \\
\text { control over the activities of } \\
\text { executive bodies }\end{array}$ & $\begin{array}{l}\text { - Developing a consolidated position of social } \\
\text { dialogue sides on the strategy of economic } \\
\text { and social development of Ukraine and ways } \\
\text { of solving existing problems in this area. } \\
\text { - Preparation and provision of agreed recom- } \\
\text { mendations and proposals to the President } \\
\text { of Ukraine, the Verkhovna Rada of Ukraine } \\
\text { and the Cabinet of Ministers of Ukraine con- } \\
\text { cerning the issues of formation and imple- } \\
\text { mentation of the state economic and social } \\
\text { policy, regulation of labor, economic and } \\
\text { social relations }\end{array}$ \\
\hline \multicolumn{2}{|c|}{ The mechanism of daily work } \\
\hline $\begin{array}{l}\text { Within the work of the com- } \\
\text { mittees }\end{array}$ & Within the work of the committees \\
\hline \multicolumn{2}{|c|}{ Organization of work at the regional level } \\
\hline $\begin{array}{l}\text { Public councils at regional and } \\
\text { district executive authorities and } \\
\text { local self-government bodies }\end{array}$ & Territorial offices at the oblast level \\
\hline \multicolumn{2}{|c|}{ Prospects for implementation of the adopted decisions } \\
\hline $\begin{array}{l}\text { The decisions are of a recom- } \\
\text { mendatory nature }\end{array}$ & $\begin{array}{l}\text { Signed by the participants in the dialogue } \\
\text { of the agreement are binding, the proposals } \\
\text { developed are of a recommendatory nature }\end{array}$ \\
\hline \multicolumn{2}{|c|}{ Participation of state authorities } \\
\hline Formally minimized & Immediate \\
\hline
\end{tabular}

Notes: compiled by the authors on the basis of $[17,18]$.
The presented conclusions allow to state the necessity of conducting an activities audit for both institutions and their structural reorganization. It is recommended instead of two separate institutions to create one - a national socio-economic council, whose activities should be carried out both at the national and local (regional and territorial) levels within the framework of realization of state and regional strategies of social and economic development.

\section{SWOT analysis of research results}

Strengths. The strengths of the research are that the proposed algorithm for analyzing the activities of public institutions allows to characterize qualitatively the effect of the structure functioning, to identify promising measures and those that should be abandoned. This study also substantiated the main institutions responsible for the development of civil society in Ukraine, and provided a detailed description of their activities at the regional level.

Weaknesses. The weaknesses of the obtained results are that the proposed system of public institutions can perform its functions with significant constraints. But the structures working in this area do not have motivations and incentives to interact with each other. A recommended approach to assessing the economic efficiency of the activities of these institutions may not be carried out, as there are no established reports on current activities carried out purely on formal grounds.

Opportunities. The obtained results create opportunities and substantiate the necessity for liquidation of the old and the formation of a new structure - the national socio-economic council, designed to introduce the principles of active involvement of the average population and economic entities in the process of public administration and reform of economic relations.

Threats. The introduction of the new recommended public structure should be accompanied by relevant legislative and regulatory acts. Taking into account the bureaucracy and lack of initiative of the majority of representatives of regional authorities and the passivity of the local community, the proposed process of reorganization and reform of economic relations can be delayed for years and grow into chronic.

\section{Conclusions}

1. The conducted analysis of the public institutions system shows that for today, their functioning is considered purely in the plane of public administration. Effectiveness and economic efficiency of their activities are practically not carried out.

2. According to the research results, an algorithm for qualitative activities analysis of public institutions was proposed based on the principle of matching the activity purpose and the event to achieve it.

3. Analysis of the current activity of existing public institutions types at the regional level has proved the inability of existing structures to implement real public initiatives:

- none of them covers the public in full;

- the majority of participants are incompetent in the areas to which these organizations are involved;

- there is no system of responsibility for non-fulfillment of duties within the framework of public institutions work. 
4. Taking in to account the identified shortcomings, duplication of functions and ineffective activities of existing public institutions, it is necessary to reorganize them and create one structure based on existing ones. This structure is intended to unite all participants in the social dialogue in order to form effective partnership relations and conduct positive reforms for the socio-economic regions development and the successful regulation of economic relations between the regions and the state.

\section{References}

1. Holub A. The mood of the Donbas // The Ukrainian Week. 2018. No. 5 (123). P. $20-25$.

2. Dosvid obiednannia terytorialnykh hromad na Skhodi Ukrainy: ekonomiko-pravovi aspekty: monograph / ed. by Ustymenko V. A., Zablodska I. V. Kyiv: TOV «VISTKA», 2018. 210 p.

3. Vasylychev D. V Sotsialno-trudovi vidnosyny v rehioni v umovakh detsentralizatsii / ed. by Pokataiev O. V., Kucherov H. Yu. // Detsentralizatsiia ta terytorialna konsolidatsiia v Ukraini: instytutsiini ta finansovo-ekonomichni zasady: monograph. Zaporizhzhia: KPU, 2016. 208 p.

4. Pro informatsiiu: Law of Ukraine No. 2658-XII from 02.10 .1992 Vidomosti Verkhovnoi Rady Ukrainy (VVR). 1992. No. 48 st. 651. URL: http://zakon2.rada.gov.ua/laws/show/2657-12

5. Pro derzhavnu statystyku: Law of Ukraine No. 2615-XII from 17.09.1992 // Verkhovnoi Rady Ukrainy (VVR). 1992. No. 43 st. 608. URL: http://zakon5.rada.gov.ua/laws/show/2614-12

6. Pro bukhhalterskyi oblik ta finansovu zvitnist v Ukraini: Law of Ukraine No. 996-XIV from 16.07.1999 // Verkhovnoi Rady Ukrainy (VVR). 1999. No. 40. st. 365. URL: http:// zakon2.rada.gov.ua/laws/show/996-14

7. Balanced Scorecard Step-By-Step / ed. by Niven P. R. John Wiley \& Sons, Inc., 2012. 318 p. doi: http://doi.org/10.1002/ 9781119205081

8. Vugal'ter A. L. Fundamental'naya ekonomiya. Dinamika. Moscow: ZAO «Izdatel'stvo «Ekonomika», 2007. $371 \mathrm{p}$.

9. Stuart-Kotze R. Performance: The Secrets of Successful Behaviour. Pearson Education Canada, 2008. 304 p.

10. Lawson R., Desroches D., Hatch T. Scorecard Best Practices: Design, Implementation, and Evaluation. Wiley, 2008. 176 p.
11. De Vasconcellos e Sa J. A. S. Strategy Moves: 14 Complete Attack and Defence Strategies for Competitive Advantage. FT Press, 2005. 256 p.

12. Pro spryiannia rozvytku hromadianskoho suspilstva v Ukraini: Decree of the President of Ukraine No. 68/2016 from 26.02.2016. URL: http://www.president.gov.ua/documents/682016-19805

13. Rehionalni plany zakhodiv shchodo realizatsii Natsionalnoi stratehii spryiannia spryiannia rozvytku hromadianskoho suspilstva u Luhanskii oblasti ta zvity pro yikh vykonannia // Luhanska oblasna derzhavna administratsiia. URL: http://loga.gov.ua/oda/about/ depart/dep_uvp/regionalni_plani_zahodiv_shchodo_realizaciyi_ nacionalnoyi_strategiyi_spriyannya_spriyannya_rozvitku

14. Rudovska S. I. Public councils of new format: organizational and legal changes of their activity // Derzhavne upravlinnia: udoskonalennia ta rozvytok. 2015. No. 9. URL: http://www. dy.nayka.com.ua/?op=1\&z=894

15. Sklad hromadskoi rady pry oblderzhadministratsii // Luhanska oblasna derzhavna administratsiia. URL: http://loga.gov.ua/ oda/about/depart/dep uvp/gr-oda/structure

16. Kilkisnyi ta personalnyi sklad komitetiv Natsionalnoi rady // Natsionalna trystoronnia sotsialno-ekonomichna rada. URL http://www.ntser.gov.ua/work-groups/515

17. Pro natsradu // Natsionalna trystoronnia sotsialno-ekonomichna rada. URL: http://www.ntser.gov.ua/pro nazradu/page7

18. Pro zabezpechennia uchasti hromadskosti u formuvanni ta realizatsii derzhavnoi polityky: Resolution of the Cabinet of Ministers of Ukraine No. 996 from 03.11.2010. URL: http:// zakon2.rada.gov.ua/laws/show/996-2010-\%D0\%BF

19. Pro zatverdzhennia Derzhavnoi stratehii rehionalnoho rozvytku do 2020 roku: Resolution of the Cabinet of Ministers of Ukraine No. 385 from 06.08.2014. URL: http://zakon2.rada. gov.ua/laws/show/385-2014-n

Calinescu Tetyana, Doctor of Economic Sciences, Professor, Department of Finance National Aerospace University named af ter M. Zhukovsky «Kharkiv Aviation Institute», Ukraine, e-mail tetyana.calinescu@gmail.com, ORCID: http://orcid.org/0000-00034919-5788

Zelenko Olena, PhD, Department of International Economics and Tourism, Volodymyr Dahl East Ukrainian National University, Severodonetsk, Luhansk region, Ukraine, e-mail: zelenko.olena@gmail.com, ORCID: http://orcid.org/0000-0003-4880-246X 